\title{
Ascending beyond the root of the problem: Aortic root replacement with and without hemiarch repair
}

\author{
Tomasz A. Timek, MD, PhD
}

\author{
From the Division of Cardiothoracic Surgery, Spectrum Health, Grand Rapids, Mich. \\ Disclosures: Author has nothing to disclose with regard to commercial support. \\ Received for publication Nov 5, 2016; accepted for publication Nov 8, 2016; available ahead of print Dec 9, 2016 \\ Address for reprints: Tomasz A. Timek, MD, PhD, Michigan State University College of Human Medicine, \\ Division of Cardiothoracic Surgery, Spectrum Health, 100 Michigan Ave NE, Grand Rapids, MI \\ 94305-5407 (E-mail: tomasz.timek@ spectrumhealth.org). \\ J Thorac Cardiovasc Surg 2017;153:1409-10 \\ $0022-5223 / \$ 36.00$ \\ Copyright (C) 2016 by The American Association for Thoracic Surgery \\ http://dx.doi.org/10.1016/j.jtcvs.2016.11.008
}

Aortic root replacement has been shown to provide very good clinical outcomes in large-scale ${ }^{1}$ and single-center ${ }^{2}$ studies. In this issue of the Journal, Preventza and colleagues $^{3}$ from Baylor up the ante by presenting an impressive series of 140 patients who underwent primary elective aortic root replacement, 119 of whom underwent concurrent hemiarch repair. The study reports no mortality, strokes, or renal failure requiring dialysis in the hemiarch group, nor any difference in composite adverse events between the patients with and without hemiarch repair. On the basis of these results, Preventza and colleagues ${ }^{3}$ conclude that the addition of hemiarch repair to aortic root surgery does not adversely impact perioperative mortality and morbidity. These investigators deserve praise for these exemplary outcomes, which may be related to a detailed and standardized cerebral protection regimen during hemiarch repair. All patients received anterograde cerebral perfusion during hemiarch repair, predominantly through the innominate artery. Moderate systemic hypothermia $\left(23.7^{\circ} \mathrm{C}\right)$ was used, with near-infrared spectroscopy-driven flow rate adjustments. The distal anastomosis was performed in expedited fashion, with a mean anterograde cerebral perfusion time of only 18 minutes, which possibly was facilitated by relatively normal distal aortic size as evidenced by the median graft size of $24 \mathrm{~mm}$. Because cerebrovascular events are a major driver of mortality in aortic surgery, ${ }^{4}$ avoidance of neurologic complications, no small feat in this sizable series, is paramount. This does not discount but only reflects the extensive experience with aortic surgery and operative acumen of these investigators.

The outcomes presented, however, must be viewed in the appropriate context. The patients in the study of Preventza and colleagues ${ }^{3}$ were young and underwent elective primary aortic root operations with essentially a "prophylactic" hemiarch replacement and thus represent an optimal clinical cohort. In a series of 142 such patients undergoing aortic root replacement with concurrent distal aortic

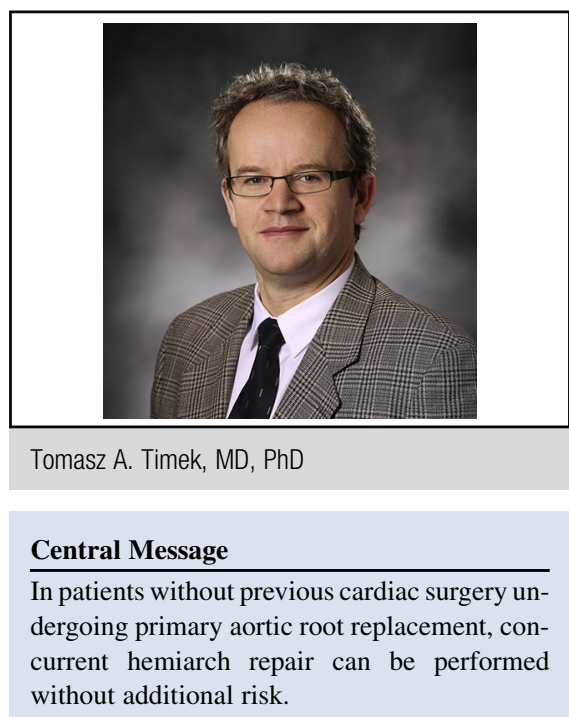

See Article page 1402 .

replacement under hypothermic circulatory arrest, Hagl and associates $^{2}$ reported similar results, with $0.7 \%$ mortality and $1.4 \%$ stroke rate. The pacemaker rate in that series was only $1.4 \%$, whereas it was substantially higher in the study of Preventza and colleagues ${ }^{3}$ at $9.2 \%$. Addition of hemiarch repair in patients at higher risk undergoing aortic root replacement ${ }^{5}$ or those undergoing isolated aortic valve replacement ${ }^{6}$ has also been shown not to influence perioperative mortality or morbidity. The comparison group in the study of Preventza and colleagues $^{3}$ of those who underwent isolated aortic root replacement was quite small, with only 21 patients, and therefore the rates of tracheostomy, pacemaker implantation, and stroke were exacerbated by a small denominator. This really brings into question the need to include the "control" group, which was small and fraught with higher complication rates than would be expected. The excellent outcome data of 119 patients with aortic root replacement and hemiarch repair, although not novel, stand on their own.

With this report, Preventza and colleagues ${ }^{3}$ have raised the bar of surgical expectations, but caution should be exercised in generalizing these results to other clinical populations or operative strategies. In the presented clinical context, Preventza and colleagues $^{3}$ have demonstrated that hemiarch repair at the time of aortic root replacement is very safe and when indicated can be pursued without 
additional risk. These data provide a foothold to ascend beyond the problem at the root.

\section{References}

1. Stamou SC, Williams ML, Gunn TM, Hagberg RC, Lobdell KW, Kouchoukos NT. Aortic root surgery in the United States: a report from the Society of Thoracic Surgeons database. J Thorac Cardiovasc Surg. 2015;149:116-22.e4.

2. Hagl C, Strauch JT, Spielvogel D, Galla JD, Lansman SL, Squitieri R, et al. Is the Bentall procedure for ascending aorta or aortic valve replacement the best approach for long-term event-free survival? Ann Thorac Surg. 2003;76:698-703; discussion 703 .

3. Preventza O, Coselli JS, Price MD, Simpson KH, Yafei O, de la Cruz K, et al. Elective primary aortic root replacement with and without hemiarch repair in patients with no prior cardiac surgery. J Thorac Cardiovasc Surg. 2017; 153:1402-8.

4. Hagl C, Khaladj N, Karck M, Kallenbach K, Leyh R, Winterhalter M, et al. Hypothermic circulatory arrest during ascending and aortic arch surgery: the theoretical impact of different cerebral perfusion techniques and other methods of cerebral protection. Eur $J$ Cardiothorac Surg. $2003 ; 24: 371-8$.

5. Malaisrie SC, Duncan BF, Mehta CK, Badiwala MV, Rinewalt D, Kruse J, et al. The addition of hemiarch replacement to aortic root surgery does not affect safety. J Thorac Cardiovasc Surg. 2015;150:118-24.e2.

6. Peterss S, Charilaou P, Dumfarth J, Li Y, Bhandari R, Tranquilli M, et al. Aortic valve disease with ascending aortic aneurysm: impact of concomitant rootsparing (supracoronary) aortic replacement in nonsyndromic patients. J Thorac Cardiovasc Surg. 2016;152:791-8.e1. 